\title{
Relationship between work context and sleep problems of high school teachers
}

\author{
Relação entre o contexto de trabalho e problemas de sono em professores do ensino médio \\ Relación entre contexto laboral y problemas de sueño en profesores de escuela secundaria
}

\begin{abstract}
Objective: The teaching function is related to work overload and health problems, including sleep problems. However, is there a relationship between sleep problems and aspects of work? In view of this, this study aimed to assess the relationship between the work context, the quality of sleep and the daytime sleepiness of teachers from public schools in Rio Grande do Norte (RN). Methodology: This study was conducted in 9 schools with 61 teachers of both genders who filled the work context assessment scale, the Pittsburgh Sleep Quality Index and the Epworth Sleepiness Scale. Results and Discussion: The majority evaluated Working Conditions and Work Organization as critical/severe, and half of them considered Socio-Professional Relations as critical/severe. Poor sleep quality was observed in 69\% of teachers, regardless of gender and excessive daytime sleepiness was observed in $49 \%$ of teachers, most often in women (55\%) compared to men. Nevertheless, there was no significant relationship between work context and sleep problems. In relation to sleep schedule, it was observed that teachers present late sleep time (23: 26 $\pm 1: 25 \mathrm{~h})$ and early wake up time (6: $06 \pm 1: 16 \mathrm{~h})$ which may have resulted in short sleep duration (6: $10 \pm 1: 07 \mathrm{~h})$. Conclusion: These results demonstrate that, in general, public school teachers in RN present complaints related to the work context and sleep problems. However, studies with a more representative sample are needed to assess as the factors related to the work context may be contributing to sleep problems. Furthermore, there is a need to create spaces for discussion with teachers in order to improve the work context and public policies aimed at education.
\end{abstract}

Keywords: Sleepiness; Sleep; Occupational health; School teachers.

\section{Resumo}

Objetivo: A função docente é relacionada com sobrecarga de trabalho e problemas de saúde, incluindo os problemas de sono. Contudo, existe uma relação entre os problemas de sono e os aspectos do trabalho? Diante disto, este estudo objetivou avaliar a relação entre o contexto de trabalho, a qualidade do sono e a sonolência diurna de professores de escolas públicas do Rio Grande do Norte (RN). Metodologia: Este estudo foi realizado em 9 escolas com 61 professores de ambos os sexos, que responderam a Escala de Avaliação do Contexto de Trabalho, o Índice de Qualidade do Sono de Pittsburgh e a Escala de sonolência de Epworth. Resultados e discussão: A maioria dos professores avaliou as Condições de Trabalho e Organização do Trabalho como críticas/graves e metade dos professores considerou as Relações Socioprofissionais como críticas/graves. A má qualidade do sono foi observada em $69 \%$ dos professores, independentemente do sexo e a sonolência diurna excessiva foi observada em $49 \%$ dos professores, sendo mais frequentemente nas mulheres $(55 \%)$ em relação aos homens. Entretanto, não foi observada relação entre contexto de trabalho e problemas de sono. Com relação aos horários de sono, foi observado que os 
professores apresentam horários tardios de dormir (23: $26 \pm 1: 25 \mathrm{~h})$ e acordam cedo (6: $06 \pm 1: 16 \mathrm{~h}$ ), o que pode ter acarretado em redução na duração do sono (6: $10 \pm 1$ : 07h). Conclusão: Estes resultados demonstram que, de forma geral, os professores de escolas privadas do RN apresentam reclamações relacionadas ao contexto de trabalho e de problemas de sono. Contudo, estudos com uma maior amostra são necessários para melhor acessar como os fatores relacionados ao contexto de trabalho podem contribuir para os problemas de sono. Além disso, é necessário criar espaços de discussão com os professores para melhorar o contexto de trabalho e as políticas públicas voltadas à educação.

Palavras-chave: Sonolência; Sono; Saúde do trabalhador; Professores escolares.

\section{Resumen}

Objetivo: La función docente está relacionada con la sobrecarga laboral y los problemas de salud, incluidos los problemas de sueño. Sin embargo, ¿existe una relación entre los problemas del sueño y los aspectos del trabajo? Ante esto, este estudio tuvo como objetivo evaluar la relación entre el contexto laboral, la calidad del sueño y la somnolencia diurna de los docentes de las escuelas públicas de Rio Grande do Norte (RN). Metodología: Este estudio se realizó en 9 escuelas con 61 profesores de ambos sexos, quienes respondieron la Escala de Evaluación del Contexto Laboral, el Índice de Calidad del Sueño de Pittsburgh y la Escala de Somnolencia de Epworth. Resultados y discusión: La mayoría de los docentes evaluó las Condiciones de Trabajo y la Organización del Trabajo como críticas / serias y la mitad de los docentes consideró las Relaciones Socioprofesionales como críticas / serias. Se observó mala calidad del sueño en el $69 \%$ de los docentes, independientemente del sexo, y somnolencia diurna excesiva en el $49 \%$ de los docentes, siendo más frecuente en las mujeres (55\%) en relación a los hombres. Sin embargo, no hubo relación entre el contexto laboral y los problemas de sueño. En cuanto a los tiempos de sueño, se observó que los profesores tienen horas de sueño tardías (23: $26 \pm 1: 25 \mathrm{~h}$ ) y se despiertan temprano (6: $06 \pm 1: 16 \mathrm{~h})$, lo que puede haber resultado en una reducción de la duración del sueño $(6: 10 \mathrm{~h}) . \pm 1: 07 \mathrm{~h})$. Conclusión: Estos resultados demuestran que, en general, los docentes de colegios privados en $\mathrm{RN}$ tienen quejas relacionadas con el contexto de trabajo y problemas de sueño. Sin embargo, son necesarios estudios con una muestra más amplia para acceder mejor a cómo los factores relacionados con el contexto laboral pueden contribuir a los problemas del sueño. Además, es necesario generar espacios de discusión con los docentes para mejorar el contexto laboral y las políticas públicas orientadas a la educación.

Palabras clave: Somnolencia; Sueño; Salud del trabajador; Maestros.

\section{Introduction}

Work in a social and financial context goes beyond a means of survival. It is a practice that provides the personal and professional gratification of the worker, in which concepts such as "dignity", "responsibility" and "utility" are associated with the way how the workers treat their own professional relationship (Souza, Saldanha \& Mello, 2014). Among the various forms of work, the teaching profession is of fundamental importance to society.

Working with education is a challenge, taking into consideration that teachers directly or indirectly face student violence and indiscipline (Biserra et al., 2014). In addition, these professionals perform their duties in inappropriate physical environments and do not have the support of co-workers and managers, affecting interprofessional relationships (Biserra et al., 2014).

According to the Organization for Economic Cooperation and Development (OECD, 2017), Brazilian primary school teachers have a monthly salary below the world average. This professional devaluation can contribute to teachers looking for more than one job, which is common in Brazil and makes work organization in the profession another challenge (Delcor et al., 2004).

In this context, teachers need to devote more time to reconciling classroom demands with those of pedagogical planning. It is noteworthy that these demands will vary according to the education level, the teacher work, the size of the class and the professional qualification (OECD, 2017). In addition, this work overload may be due to the lack of human resources necessary for the proper distribution of tasks (Lago, Cunha \& Borges, 2015). This demand triggers the need and the pursuit of the teacher for professional qualification courses, resulting in more overload of tasks and making the life dynamics of this professional a great temporal challenge.

Teacher working conditions have been directly associated with the health and quality of life (Tabeleão, Tomasi \& Neves, 2011). Among the health problems, teachers who start work in the morning shift, around 7:00 am, face a temporal 
challenge that leads to deprivation and poor sleep quality (Souza et al., 2014), which can also compromise the quality of life. This temporal challenge is due to the incompatibility between the biological needs of human beings regarding the sleep/wake cycle and the working hours imposed by society.

The sleep/wake cycle (SWC) is regulated by circadian and homeostatic physiological processes. The circadian regulation in humans occurs from a complex timing system that generates and regulates SWC. This system synchronizes wakefulness to occur during the daytime and sleep to occur at night from external light/dark cycle information and this occurs recurrently every 24 hours (Borbély \& Achermann, 1999).

In addition to circadian regulation, there is a homeostatic regulation, which refers to the amount of sleep and wakefulness throughout the 24 hours (Borbély \& Achermann, 1999). This regulation depends on the duration of SWC in previous days, so in sleep deprived conditions the need for sleep increases and the individual tends to compensate for more sleep hours in the following days in order to maintain the balance of their biological rhythm (Curie et al., 2013). There is an exchange of information between these two regulatory processes making them complementary about the SWC (Borbély et al., 2016).

Considering the influence of the environment on the regulation processes of the SWC and the insertion of the individual in the social world, these regulatory processes interact with each other in order to adapt the individual's sleep and wakefulness to the imposed changes. However, work routine and social demands can trigger conditions of temporal challenges for teachers, compromising the performance of circadian and homeostatic components in the regulation of SWC, which can cause damage to health and professional stress (Gasparini, Barreto \& Assunção, 2006; Reis et al., 2006).

Furthermore, other research shows that teacher sleep disturbances are more likely to occur due to the most stressful days at work, considering that job routines fluctuate, with some days being busier than others. This often causes attachment to work and bringing the thinking about work home, which may cause changes in sleep (Cropley, Dijk \& Stanley, 2006). This type of routine can have negative consequences on the performance of professional and personal activities, as well as loss of productivity and increased risk of errors, which can cause problems in workers' health (Bernardo et al., 2015).

From the perspective of the teaching profession, studies conducted with teachers contribute to the emergence of interdisciplinary discussions about what needs to be changed, preventing the feeling of loss in the sense of work from being installed in the teacher's life (Brito et al., 2014). Thus, there is a need to provide the teacher with adequate work situations, both regarding the structure and the psychosocial factors that constitute the teacher-work relationship. For this, it is imperative to consider the perception of the worker about their own work context (Meira et al., 2014).

In this scenario, the work context assessment scale (Mendes \& Ferreira, 2008) is an instrument that has been used to evaluate the work context of professionals based on three main factors: Working conditions, Work organization and Socioprofessional relations. Work conditions address the issue of the quality of the work environment in relation to the space where the activities are performed and the distribution of physical resources (Mendes \& Ferreira, 2008). Complementarily, work organization deals with the division of the obligations/tasks to be performed in the workspace, as well as the existence of imposed norms, control of the routine and the rhythms of the activities. The socio-professional relationships address the interaction of work with colleagues who share the same occupation and setting, as well as the ability for professional interactions (Mendes \& Ferreira, 2008).

Consequently, the use of this scale in teaching may clarify how teachers perceive the confrontations associated with their profession and may contribute to developing future strategies. Therefore, this study aims to evaluate the relationship between the teaching work context with sleep quality and daytime sleepiness of high school teachers in public schools in the countryside of Rio Grande do Norte. 


\section{Methodology}

The methodology used in this study was based in the scientific method with a quantitative approach (Pereira et al., 2018). This is a cross-sectional, descriptive and exploratory study conducted with high school teachers from public schools in the countryside of Rio Grande do Norte (RN), Brazil. According to the National Institute for Studies and Research (INEP, 2018), northeastern Brazil has an average of 31.7 students per class in high school, with repetition and dropout rates of $10.1 \%$ and $6.7 \%$, respectively. In addition, $10 \%$ of high school teachers do not have higher education (INEP, 2018). The state of RN has 57.92\% of the schools with a Socioeconomic Level of Basic Education Schools inside group 3 (INEP, 2015). This classification developed by INEP classifies the socioeconomic level of the schools into 6 groups, with group 1 having the smallest and group 6 the largest Socioeconomic Level of Basic Education, respectively. Moreover, in 2010 the RN presented a Human Development Index (HDI) of 0.684, which is considered middle, with longevity, income and education being the dimensions that most contributed to the HDI (Atlas, 2013). In this context, data collection was performed with teachers from 9 schools in the Trairi region of RN, which has 11 schools, distributed in nine municipalities.

The guideline for biological rhythm research in humans was followed and this study was approved by the Research Ethics Committee of the Trairi School Health Sciences under the CAAE number 56720716.8.0000.5568. Sixty-eight (68) teachers of both genders who signed the Consent Form participated in this research. Teachers who taught at the study school for at least 6 months in fulfilling their professional demands in the classroom were included. Seven teachers who reported conditions which could influence the study results were excluded from the analysis. Among them, 4 reported anxiety and fibromyalgia, and 3 not fully answering the questionnaires. Therefore, the final sample was 61 teachers.

The data were collected between September 2016 to May 2017, excluding periods of school recess or vacation, or public holiday, and the interviews were conducted after teachers had been working for at least 30 days. This last criterion was used to evaluate sleep parameters during the work routine, eliminating the influence of vacation or recess.

The instruments used in this study were: 1. Participant Identification Card, which accesses age, gender, marital status, teaching time and health condition; 2. The Work Context Assessment Scale (WCAS), which is composed of three factors; the first is the working condition that assesses the quality of the work environment; the second is the work organization that deals with questions about division of labor in the job through the obedience of norms and control of the accomplishment of the activities and the work rhythm; and the third factor is the socio-professional relations which evaluates work management, and the communication and interaction with colleagues. As a result, the teacher evaluates their work context as satisfactory, critical or severe according to the average obtained through the scale responses. In this study, averages below 2.3 were considered as a satisfactory working context, while averages above 2.3 characterized a critical/severe work context (Mendes and Ferreira 2008); 3. The Pittsburgh Sleep Quality Index (PSQI) is a questionnaire consisting of 19 questions about subjective sleep quality, sleep latency, duration, use of sleep medications, sleep efficiency, disorders and daytime dysfunction. The overall score ranges from 0 to 21 , with scores less than or equal to 5 indicating good sleep quality, while scores greater than 5 indicate poor sleep quality (Bertolazi, 2008); and 4. The Epworth Sleepiness Scale (ESS) assesses the level of daytime sleepiness by routine situations in which individuals are more likely to fall asleep. This scale is made up of 8 questions each rating 0 to 3 points, with a total score from 0 to 24 points. Scores less than or equal to 10 are considered low sleepiness level and scores greater than 10 are considered excessive daytime sleepiness (Bertolazi et al., 2009).

The collected data were analyzed using SPSS version 20.0. A normality test for the sample (Kolmogorov-smirnov) was initially performed, indicating a non-parametric distribution. The Chi-squared test was used to describe the association between the variables work context, sleep quality and daytime sleepiness according to gender. The Mann Whitney test was used to compare differences in sleep quality and daytime sleepiness between the groups that rated the work context as satisfactory and critical/severe. Spearman's correlation was used to analyze the relationship between work context and sleep 
quality and sleepiness level.

\section{Results}

The average age of the teachers was $39.72 \pm 9.17$ years and the sample composition did not differ in relation to gender, being 53\% male and $47 \%$ female $\left(X^{2}=00.36 ; p>0.05\right)$. Regarding marital status, most teachers are married $(48 \%)$ or single $(39 \%)$, and $13 \%$ reported having another type of marital status $\left(X^{2}=19.84 ; p<0.001\right)$. Teachers presented an average of $15 \pm 8.3$ years in the profession, and $8 \pm 7.3$ years being a teacher in the institution in which the study was conducted.

Most teachers $(60 \%)$ work in two or more schools, while $40 \%$ work only in the school visited $\left(\mathrm{X}^{2}=4.00 ; \mathrm{p}=0.04\right)$. In addition, $88 \%$ of them taught in public school, while $12 \%$ reported teaching in public and private schools $\left(\mathrm{X}^{2}=57.76 ; \mathrm{p}\right.$ $<0.001$ ). In relation to their health conditions, $43 \%$ of teachers reported some type of health problem in the last month, such as: chronic diseases, otorhinolaryngologic diseases, gastrointestinal problems and osteoarticular diseases.

Regarding the evaluation of the work context, the majority of teachers evaluated the factors "Working Conditions" $\left(68 \%-\mathrm{X}^{2}=12.96 ; \mathrm{p}<0.05\right)$ and "Work Organization" $\left(80 \%-\mathrm{X}^{2}=16.00 ; \mathrm{p}<0.05\right)$ as critical/severe, respectively (Figure 1$)$.

Figure 1 - Percentage of teachers that evaluate the work context as satisfactory or critical/severe according to the factors: working conditions, work organization and socio-professional relationships.

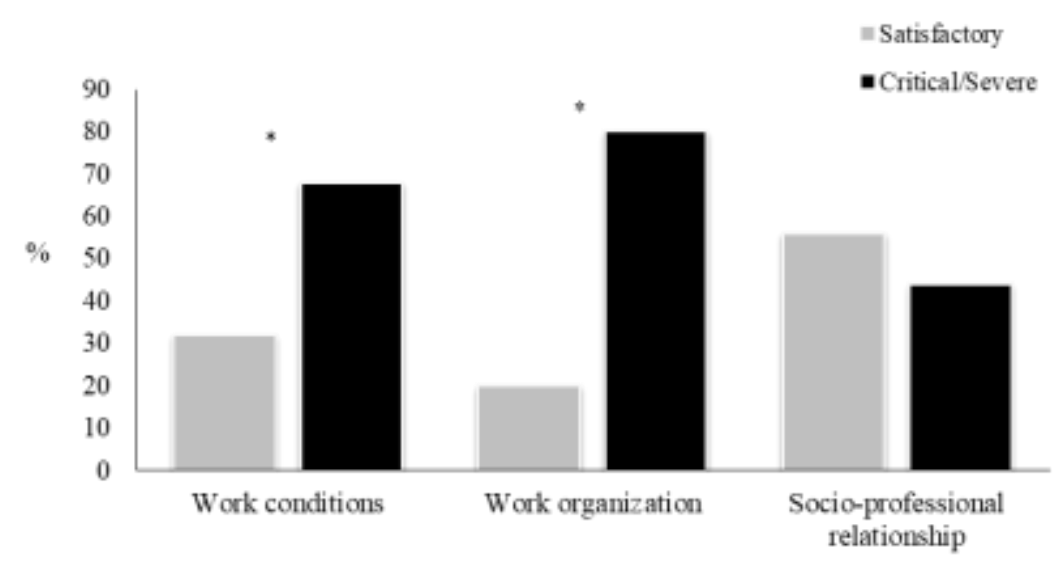

Note: The * indicate significant difference between the percentage distribution as satisfactory and critical/severe of the work context according to the factors, Chi-square; $\mathrm{p}<0.05$.

Source: Research data.

In addition, $44 \%$ of teachers reported "Socio-professional Relations" as critical/severe $\left(\mathrm{X}^{2}=1.44 ; \mathrm{p}>0.05\right)$. The evaluation of these work context factors did not differ according to gender (Working Conditions: $\mathrm{X}^{2}=0.04$; Work Organization: $X^{2}=0.60$ and Socio-professional Relations: $X^{2}=0.04$ - Figure 2). 
Figure 2 - Percentage of teachers that evaluate the work context as critical/severe according to sex.

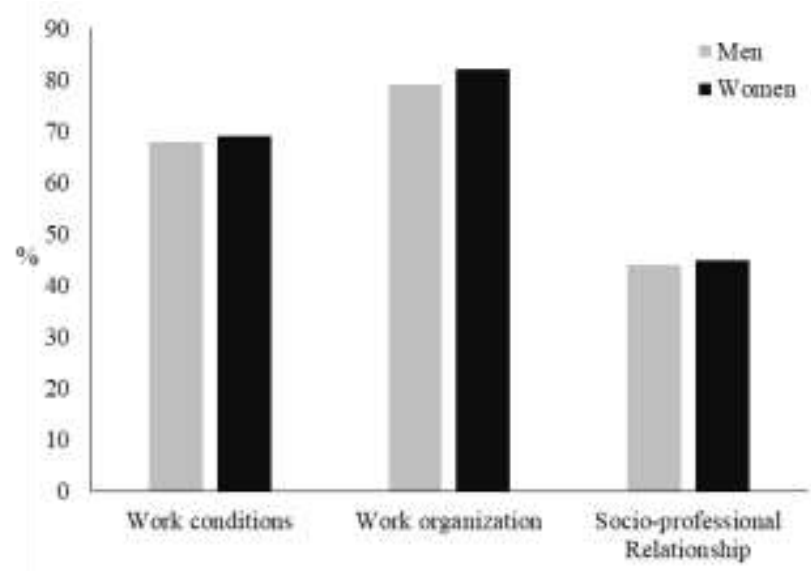

Note: No significant difference was observed, Chi-square; $p>0.05$. Source: Research data.

Concerning the items that constitute each factor, it is important to highlight that 9 out of the 10 items of the factor "Working conditions" were evaluated as critical/severe. In the "Work Organization" factor, all 11 items were assessed as critical/severe. Meanwhile, the factor "Socio-professional Relations" presented only half of the items evaluated as critical/severe (Table 1).

Table 1 - Mean and standard deviation (SD) of the results obtained in the items of each factor in the WCAS.

\begin{tabular}{|c|c|c|}
\hline \multirow{11}{*}{$\begin{array}{l}\text { WORKING } \\
\text { CONDITIONS }\end{array}$} & & MEAN \pm SD \\
\hline & Poor working conditions & $2,69 \pm 1,02 *$ \\
\hline & Uncomfortable physical environment & $3,07 \pm 1,07 *$ \\
\hline & Noisy environments & $3,31 \pm 1,00 *$ \\
\hline & Inadequate school furniture & $2,79 \pm 1,00^{*}$ \\
\hline & Insufficient working tools & $2,77 \pm 1,05^{*}$ \\
\hline & Inadequate workstation & $2,54 \pm 0,86^{*}$ \\
\hline & Precarious equipment & $2,75 \pm 0,88 *$ \\
\hline & Inadequate physical space & $2,49 \pm 1,02 *$ \\
\hline & Risks to the safety of people & $2,28 \pm 1,12$ \\
\hline & Insufficient material & $2,63 \pm 0,95^{*}$ \\
\hline \multirow{11}{*}{$\begin{array}{c}\text { WORK } \\
\text { ORGANIZATION }\end{array}$} & Pace of work & $3,34 \pm 1,26^{*}$ \\
\hline & Tasks accomplished under pressure & $3,25 \pm 1,28 *$ \\
\hline & Demand for results & $3,39 \pm 1,20 *$ \\
\hline & Rigid rules & $2,92 \pm 1,08 *$ \\
\hline & Performance inspection & $3,08 \pm 1,22 *$ \\
\hline & Insufficient number of people & $2,89 \pm 0,96^{*}$ \\
\hline & Expected results out of reality & $3,02 \pm 1,04 *$ \\
\hline & Lack of time to rest & $3,21 \pm 1,34 *$ \\
\hline & Division between who planning and who executing & $2,80 \pm 1,37 *$ \\
\hline & Repetitive tasks & $3,15 \pm 1,06^{*}$ \\
\hline & Tasks are discontinued & $2,98 \pm 1,17 *$ \\
\hline \multirow{10}{*}{$\begin{array}{c}\text { SOCIO- } \\
\text { PROFESSIONAL } \\
\text { RELATIONS }\end{array}$} & Tasks not clearly defined & $2,36 \pm 1,18^{*}$ \\
\hline & Non-existent autonomy & $2,33 \pm 1,13^{*}$ \\
\hline & Unfair task distribution & $2,20 \pm 1,12$ \\
\hline & Teachers are excluded from decision-making & $2,15 \pm 1,13$ \\
\hline & Communication between management and subordinates & $2,30 \pm 1,10^{*}$ \\
\hline & Professional disputes & $2,02 \pm 1,04$ \\
\hline & Lack of integration & $2,62 \pm 1,01 *$ \\
\hline & Poor employee communication & $2,49 \pm 1,14 *$ \\
\hline & Difficult to access information & $2,23 \pm 0,99$ \\
\hline & Lack of management support & $2,23 \pm 1,03$ \\
\hline
\end{tabular}

Note: * indicate items rated as critical/severe. Source: Research data. 
In relation to teachers' sleep/wake patterns, a bedtime average of 23:26 $\pm 1: 25 \mathrm{~h}$, wake up time at 6:06 $\pm 1: 16 \mathrm{~h}$, and sleep duration of 6:10 $\pm 1: 07 \mathrm{~h}$ were observed. Most teachers $(69 \%)$ were classified with having poor sleep quality $\left(\mathrm{X}^{2}=14.44\right.$; $p<0.05)$, regardless of gender $\left(X^{2}=0.00 ; p>0.05\right)$. Half of them $(49 \%)$ had excessive daytime sleepiness $\left(X^{2}=0.04 ; p>\right.$ $0.05)$, with a higher prevalence among women $(55 \%)$ than men $\left(45 \%-\mathrm{X}^{2}=4.88 ; \mathrm{p}<0.05\right)$.

Comparing the groups of teachers who evaluated the work context as "satisfactory" and "critical/severe", it was observed poor sleep quality in the group that rated the socio-professional relations factor as "critical/severe" (U $=321, \mathrm{p}<$ $0.05)$. However, no difference in the classification of sleep quality was observed between the groups regarding the factors working conditions and work organization, as well as for the three factors regarding the level of daytime sleepiness.

Additionally, it was found that teachers with poor sleep quality had 36 minutes less sleep than those with good sleep quality ( $\mathrm{U}=256.00 ; \mathrm{p}<0.05)$.

According to the Spearman's correlation, there was no relationship between work context factors and sleep quality (Working Conditions $-\rho=0.14$, Work Organization $-\rho=0.01$ and Socio-Professional Relations $-\rho=0.20 ; p>0.05$ ) and daytime sleepiness (Working conditions $-\rho=-0.06$, Work organization $-\rho=0.02$ and Socio-professional relations $-\rho=-$ $0.04 ; \mathrm{p}>0.05)$.

\section{Discussion}

In this study, the teachers subjectively evaluated their own work context, classifying the factors "Working Conditions" and "Work Organization" as critical/severe. This study addressed the teaching work context in an unprecedented way through the Work Context Assessment Scale (WCAS) and related the work conditions and organization, and the socioprofessional relationships with the sleep conditions of high school teachers.

Regarding working conditions, teachers considered the equipment conditions as precarious, insufficient working instruments, furniture and physical space as inadequate and uncomfortable, and the work environment very noisy. These conditions may directly impact developing the activities of these teachers.

Unfavorable working conditions negatively imply on the teacher's permanence in the profession and their own vision regarding their professional valorization (Masson, 2017). It further argues that discussions on the subject can contribute to better career planning for the teaching public in order to ensure greater appreciation of this individual within the school. Therefore, considering that the teacher has poor working conditions, it is important to reflect on prevention and promotion of quality of life at work in order to ensure sufficient subsidies for good teaching practice (Tabeleão, Tomasi \& Neves, 2011).

Regarding the organization of teaching work, it was observed that teachers consider the pace of work critical and with insufficient numbers of people. This assessment may be related to teaching work overload, considering that most teachers $(60 \%)$ reported teaching in two or more schools, which can also compromise their work pace and performance at work.

Many teachers may seek out more than one employment in an attempt to increase family income, which can contribute to a necessity to adapt to different labor rules and consequently to stress (Vasconcelos-rocha et al., 2016). Beyond the low salaries of the category and the negative perception of remuneration which induce teachers to pursue multiemployment, the teaching function is also characterized as excessive workload with numerous activities inside and outside schools, and the large number of students in the classroom (Birolim et al., 2019).

The teachers in this study rated items which refer to tasks performed under pressure as critical/severe, with performance oversight and charging for results. In view of this, it is important that teachers have spaces in the workplace which provide an exchange of experiences and social support. It is also necessary to perform a reflection in the school environment about the real work context problems faced by teachers, seeking to clarify the causes and structural determinations. 
Another critical assessment observed in this study was the item "lack of time to rest", which may have contributed to the participants in this study reporting a reduced average sleep time of 6:10h. According to the National Sleep Foundation, adults are recommended to have 7 to 9 hours of sleep per night (Hirshkowitz et al., 2015). Therefore, the teachers in this study presented sleep deprivation, which may be related to numerous health problems and decreased quality of life.

A study with high school teachers from schools in the capital of Rio Grande do Norte also found a reduction in sleep on working days, and similar bedtime and wake-up times (Souza et al., 2012). It is important to emphasize that the data collection instrument used in this study to access sleep/wake schedules were different. However, the results observed in both studies were very close.

The earlier wake-up time may be due to the start time of classes in the morning, around 7 am in Brazil. Meanwhile, bedtime may be linked to high demands in the classroom (class preparation, exercise correction), computer use at night, and domestic chores (Souza et al., 2012). Therefore, sleep deprivation observed in teachers may be due to a late bedtime added to starting work very early in the morning.

Regarding sleep quality and excessive daytime sleepiness, the results found in this study corroborate the findings of a study conducted with 131 teachers from Natal/RN, in which the authors found poor sleep quality in most teachers and excessive daytime sleepiness in half of them (Souza et al., 2016). Our study found that teachers classified with poor sleep quality presented a sleep duration 36 minutes shorter than teachers with good sleep quality, which demonstrates that sleep deprivation is even higher for these teachers.

Despite the poor sleep quality and excessive sleepiness observed in the teachers of this study, no relationship was observed between sleep variables and work context. Therefore, sleep variables may have been influenced by some lifestyle habits of individuals. For example, a study of Brazilian teachers found that $52 \%$ of them were classified with poor sleep quality, they spent more time watching television, they did not engage in physical activity, were obese, and consumed little coffee (Souza et al., 2017).

Therefore, the high frequency of poor quality observed in this study may be influenced by the lifestyle habits of these teachers. However, it is important to emphasize that some of the inappropriate habits may be due to the demands of the teaching profession itself, such as using a computer at night for class preparation or professional qualification.

A Japanese study with teachers, administrators, and other workers in an educational institution found that the majority (66.3\%) of teachers did not have excessive daytime sleepiness (Amschler \& Mckenzie, 2010), while half of teachers in this study had excessive daytime sleepiness. Factors related to the higher prevalence of daytime sleepiness observed in Brazilian teachers should be further investigated, given that Japanese teachers have some of the longest working hours among participating countries in OECD data (OECD, 2017).

Research about teachers' work context with approaches to health promotion, physical and mental symptoms, work organization, and public policies are not enough to articulate practices that benefit teaching performance. This context does not contribute to optimizing the work and to appropriate health for this population (Cortez et al., 2017). Considering the results observed in this study we suggest that more research about work context and sleep must be performed, including broader aspects of the work context, as well as factors such as satisfaction and professional attachment.

\section{Conclusion}

Considering that teachers of this study evaluated the factors and working conditions and work organization as critical/severe, and presented sleep-related impairments, this study reinforces the need for creating discussion spaces where the workers themselves also express demands and collectively construct proposals for solutions. In this way, we can contribute to creating policies and actions to improve the work context and consequently quality of life at work. 
It is noteworthy that a limitation observed during data collection was the low adherence of teachers to the study led to a reduced sample, which decreases the generalization power of the results. The main reason reported by teachers to justify nonadherence was their lack of time to complete the questionnaires, given that many teachers have more than one shift of work and work at two or more schools. However, the results observed in this study should be considered by future studies which seek to understand how to contribute to improving the teaching work context, as well as the possible impacts on the health of these professionals.

In addition, the results of this study should be considered by school managements with the aim to promote changes which favor the quality of the environment and the work performed. Organization of the workspace, in addition to the physical arrangement and infrastructure of the schools should be considered, including issues such as the work pace, planning and division of teaching tasks and management of available human and material resources. They should also seek to strengthen public policies so that issues such as remuneration, less students in the classroom and safety at schools are raised in agendas with the purpose of changing this reality.

\section{Acknowledgments}

Ricardo Andrade for his contribution and assistance in the statistical analysis of the data. To teachers and school principals who agreed to share their experiences and authorized entry into schools for data collection, respectively. To the Graduate Program in Collective Health and Trairi School of Health Sciences for their support.

\section{References}

Amschler, D. H., \& Mckenzie, J. F. (2010). Perceived sleepiness, sleep habits and sleep concerns of public school teachers, administrators and other personnel. American Journal of Health Education, [s.n.] 41 (2), 102-109.

ATLAS (2013). Atlas do Desenvolvimento Humano no Brasil. Evolução do desenvolvimento humano nos municípios brasileiros.

Bernardo, V. M., da Silva, F. C., Gonçalves, E., Hernández, S. S. S., Arancibia, B. A. V., \& da Silva, R. (2015). Efeitos do Trabalho em Turnos na Qualidade do Sono de Policiais: Uma Revisão Sistemática. Revista Cubana de Medicina Militar, 44(3), 334-345.

BertolazI, A. N. (2008). Tradução, adaptação cultural e validação de dois instrumentos de avaliação do sono: escala de sonolência de Epworth e índice de qualidade de sono de Pittsburgh. Dissertação (Mestrado em Medicina) - Universidade Federal do Rio Grande do Sul, Faculdade de Medicina, Programa de Pós-Graduação em Medicina: Ciências Médicas.

Bertolazi, A. N., Fagondes, S. C., Hoff, L. S., Pedro, V. D., Menna Barreto, S. S., \& Johns, M. W. (2009). Portuguese-language version of the Epworth sleepiness scale: validation for use in Brazil. Jornal Brasileiro de Pneumologia, 35(9), 877-883.

Birolim, M. M., Mesas, A. E., González, A. D., Santos, H. G. D., Haddad, M. D. C. F. L., \& Andrade, S. M. D. (2019). Trabalho de alta exigência entre professores: associações com fatores ocupacionais conforme o apoio social. Ciência \& Saúde Coletiva, 24, $1255-1264$.

Biserra, M. P., Giannini, S. P., Paparelli, R., \& Ferreira, L. P. (2014). Voz e trabalho: estudo dos condicionantes das mudanças a partir do discurso de docentes. Saúde e Sociedade, 23, 966-978.

Borbély, A. A., Daan, S., Wirz-Justice, A., \& Deboer, T. (2016). The two-process model of sleep regulation: a reappraisal. Journal of sleep research, 25(2), 131-143.

Borb, A. A., \& Achermann, P. (1999). Sleep homeostasis and models of sleep regulation. Journal of biological rhythms, 14(6), 559-570.

Brito, J., Bercot, R., Horellou-Lafarge, C., Neves, M. Y., Oliveira, S., \& Rotenberg, L. (2014). Saúde, gênero e reconhecimento no trabalho das professoras: convergências e diferenças no Brasil e na França. Physis: Revista de Saúde Coletiva, 24, 589-605.

Cortez, P. A., Souza, M. V. R. D., Amaral, L. O., \& Silva, L. C. A. D. (2017). A saúde docente no trabalho: apontamentos a partir da literatura recente. Cadernos Saúde Coletiva, 25(1), 113-122.

Cropley, M., Dijk, D. J., \& Stanley, N. (2006). Job strain, work rumination, and sleep in school teachers. European Journal of Work and Organizational Psychology, 15(2), 181-196.

Curie, T., Mongrain, V., Dorsaz, S., Mang, G. M., Emmenegger, Y., \& Franken, P. (2013). Homeostatic and circadian contribution to EEG and molecular state variables of sleep regulation. Sleep, 36(3), 311-323.

Delcor, N. S., Araújo, T. M., Reis, E. J., Porto, L. A., Carvalho, F. M., Silva, M. O., ... \& Andrade, J. M. D. (2004). Condições de trabalho e saúde dos professores da rede particular de ensino de Vitória da Conquista, Bahia, Brasil. Cadernos de Saúde Pública, 20, 187-196. 
Gasparini, S. M., Barreto, S. M., \& Assunção, A. Á. (2006). Prevalência de transtornos mentais comuns em professores da rede municipal de Belo Horizonte, Minas Gerais, Brasil. Cadernos de Saúde Pública, 22(12), 2679-2691.

Hirshkowitz, M., Whiton, K., Albert, S. M., Alessi, C., Bruni, O., DonCarlos, L., ... \& Hillard, P. J. A. (2015). National Sleep Foundation's sleep time duration recommendations: methodology and results summary. Sleep health, 1(1), 40-43.

OECD (2017). Education at a Glance 2017: OECD Indicators. OECD Publishing, Paris.

INEP (2018). Censo Escolar da Educação Básica. Indicadores educacionais. Manual do usuário. Brasília: Ministério da Educação; Instituto Nacional de Estudos e Pesquisas Educacionais Anísio Teixeira.

INEP (2015). Microdados do Saeb. Manual do usuário. Brasília: Ministério da Educação; Instituto Nacional de Estudos e Pesquisas Educacionais Anísio Teixeira.

Lago, R. R., Cunha, B. S., \& Borges, M. F. D. S. O. (2015). Percepção do trabalho docente em uma universidade da região norte do Brasil. Trabalho, Educação e Saúde, 13(2), 429-450.

Masson, G. (2017). Requisitos essenciais para a atratividade e a permanência na carreira docente. Educação \& Sociedade, 38(140), 849-864.

Meira, T. R. M., Cardoso, J. P., Vilela, A. B. A., Amorim, C. R., Rocha, S. V., Andrade, A. N., \& Freire, D. S. (2014). Percepções de professores sobre trabalho docente e repercussões sobre sua saúde. Revista Brasileira em Promoção da Saúde, 27(2), $276-282$.

Mendes, A. M., \& Ferreira, M. C. (2008). Contexto de trabalho. In: Mirlene Maria Matias Siqueira. Medidas do comportamental organizacional: Ferramentas de Diagnóstico e Gestão. Porto. Artmed. 111-123.

Pereira, A. S., Shitsuka, D. M., Parreira, F. J., Shitsuka, R. (2018). Metodologia de pesquisa científica. Santa Maria: IAB/NTE/UFSM. https://repositorio.ufsm.br/bitstream/handle/1/15824/Lic_Computacao_Metodologia-Pesquisa-Cientifica.pdf?sequence=1 .

Reis, E. J., Araújo, T. M. D., Carvalho, F. M., Barbalho, L., \& Silva, M. O. (2006). Docência e exaustão emocional. Educação \& Sociedade, 27(94), 229-253.

Souza, J. C. D., Galina, S. D., Almeida, J. C. F. D., Sousa, I. C. D., \& Azevedo, C. V. M. D. (2014). Work schedule influence on sleep habits in elementary and high school teachers according to chronotype. Estudos de Psicologia (Natal), 19(3), 200-209.

Souza, J. C. D., Galina, S. D., Sousa, I. C. D., \& Azevedo, C. V. M. D. (2016). Effect of a sleep education program on sleep knowledge and habits in elementary and high school teachers. Estudos de Psicologia (Natal), 21(4), 369-380.

Souza, J. C. D., Sousa, I. C. D., Belísio, A. S., \& Azevedo, C. V. M. D. (2012). Sleep habits, daytime sleepiness and sleep quality of high school teachers. Psychology \& Neuroscience, 5(2), 257-263.

Souza, S. C. S., Campanini, M. Z., de Andrade, S. M., González, A. D., de Melo, J. M., \& Mesas, A. E. (2017). Watching television for more than two hours increases the likelihood of reporting poor sleep quality among Brazilian schoolteachers. Physiology \& behavior, 179, $105-109$.

Souza, T. S. D., Saldanha, J. H. S., \& Mello, I. M. D. (2014). As relações de trabalho dos fisioterapeutas na cidade de Salvador, Bahia. Saúde e Sociedade, 23, $1301-1315$.

Tabeleão, V. P., Tomasi, E., \& Neves, S. F. (2011). Qualidade de vida e esgotamento profissional entre docentes da rede pública de Ensino Médio e Fundamental no Sul do Brasil. Cadernos de Saúde Pública, 27(12), 2401-2408.

Vasconcelos-Rocha, S., Squarcini, C. F., Paixão-Cardoso, J., \& Oliveira-Farias, G. (2016). Características ocupacionais e estilo de vida de professores em um município do nordeste brasileiro. Revista de Salud Pública, 18, 214-225. 